\title{
New data on the relations of kimberlite magmatism and diamond placers to the basement structure in the northern Yakutian kimberlite province
}

\author{
Alexander P. Smelov and Albert I. Zaitzev \\ Diamond and Precious Metal Geology Institute, Siberian Branch, Russian Academy of Sciences, Yakutsk, \\ Russia
}

The Yakutian kimberlite province within the northeastern Siberian platform occupies an area of about 400000 sq. km. (fig). In the northeastern Siberian platform, the largest worldwide province of diamond placers is discovered. The Upper Paleozoic, Mesozoic and Cenozoic placers contain about $70 \%$ of Russia's proved resources of alluvial diamonds, though their primary sources remain unknown. Abundant diamond placers are found there as well as about 700 kimberlite bodies of Paleozoic and Mesozoic age. Diamonds are either absent in the kimberlites or occur in small quantities. (Grakhanov et al., 2007; Koptil' and Bilenko, 1980).

Typomorphic features of diamonds from major placers in the northeastern Siberian platform were studied. The diamonds are divided into three main groups, which could have different primary sources.

1. The first group includes diamonds typical of kimberlites and lamproites. They normally have a heavy $\mathrm{C}$ isotope composition $\left(\delta^{13} \mathrm{C}=-4-7 \%\right)$, and are represented by laminar octahedra, cryptolaminar rhombododecahedroids of the "Brazilian" type as well as vein-type dodecahedroids with the evidence of plastic deformation. Highly diamondiferous kimberlites of Yakutia are characterized by predominant Variety I laminar diamond crystals, while in the lowdiamondiferous kimberlites rounded crystals of the "Brazilian" type prevail.

2. Referred to the second group are diamonds of the "Ebelyakh" type. These are graphitized Variety V rhombododecahedroids, aggregates of Variety VII dodecahedroids with a light $\left(\delta^{13} \mathrm{C}=-23 \%\right) \mathrm{C}$ isotope composition, as well as evenly colored Variety II cuboids with an intermediate $\mathrm{C}$ isotope composition $\left(\delta^{13} \mathrm{C}=-13,6 \%\right)$. No such diamonds were encountered in Yakutian kimberlites.

3. The third group is formed by impact diamonds, for which the primary source is the rocks of the Popigay astrobleme.
The distribution patterns and typomorphic features of diamonds and indicator minerals of kimberlites in the Proterozoic and Phanerozoic sedemetary rocks are all suggestive of three epochs of productive diamondiferous magmatism in the northeastern Siberian platform: Late Proterozoic, Middle Paleozoic and Early Mesozoic.

A possibility of discovering the Precambrian primary sources is justified by the finds of indicator minerals of kimberlites in the Late Proterozoic marine and littoralmarine rocks of the Anabar shield and the Udzha and Olenek uplifts (Grakhanov et al., 2007; Afanasiev et al., 2000).

In this connection, studying the composition, structure and age of the basement and the formation history of its relief is of prime importance for recognizing the early stages of diamondiferous magmatism and erosion processes.

\section{Position of kimberlite fields relative to tectonic structures of the basement}

The position of Phanerozoic kimberlite fields relative to the structures of the basement is shown in Fig. Analysis of the position of Paleozoic and Mesozoic kimberlite bodies with different diamond tenor relative to the Precambrian structures of the basement of the North Asian craton has revealed a certain zoning. It is expressed in that the central part of the craton contains fields of highly diamondiferous kimberlites (several carats per ton). Paleozoic and Mesozoic kimberlites in the marginal parts of the craton are poor in diamonds or barren. However, placer diamond deposits are the most widespread there. This may reflect peculiarities of tectonic evolution of the central and marginal parts of the craton. Characteristically, highly diamondiferous kimberlites are confined to the terranes of Paleoproterozoic orogenic belts $(1.9 \mathrm{Ga})$ and Archean 
cratons $(2.6 \mathrm{Ga})$ and are remote from the areas of wide distribution of Proterozoic rifts (fig).

Two large Paleoproterozoic terranes are recognized in the basement of the northeastern Siberian platform. These are the Khapchan granulite-paragneiss terrane made of the rocks with $\mathrm{Nd}$ model ages of 2.4-2.3 Ga and the Berekta composite terrane overlain by a sedimentary cover. The basement rocks of this terrane are fragmentarily exposed in the Olenek and possibly Ust'-Lena uplifts, where metamorphism is greenschist facies and granulite facies, respectively. The age of the rocks is 2.0-1.9 Ga. Collision between the two terranes occurred at 1.9-1.8 Ga. No regular relations have so far been established between the kimberlite magmatism and diamond placers, on the one hand, and the structure and composition of the Paleoproterozoic basement, on the other (Rosen et al., 1994, Smelov and Timofeev, 2007).

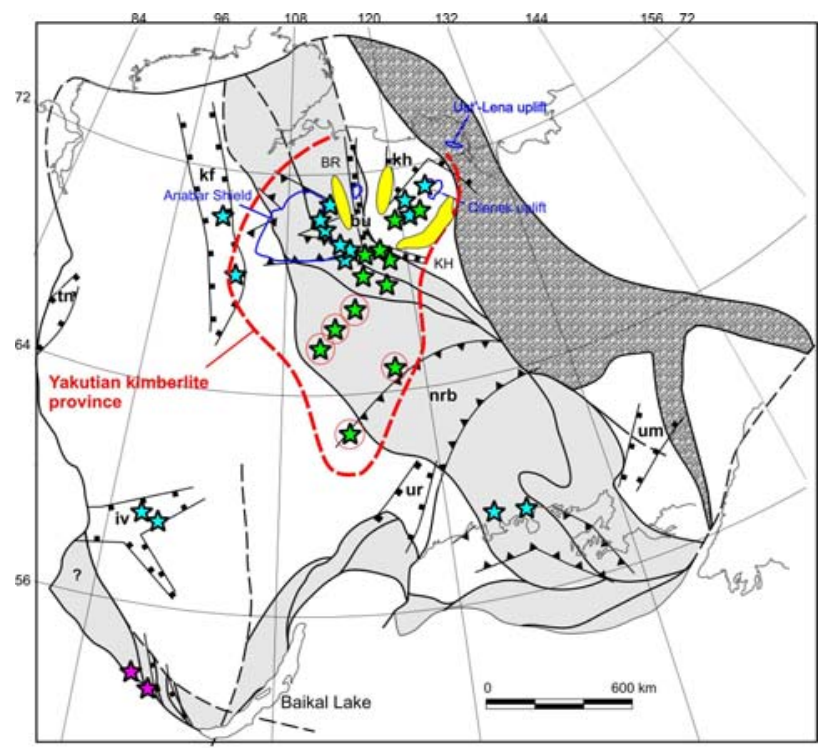

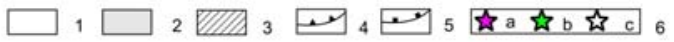

708

Fig. Position of kimberlite fields and placer areas relative to tectonic structure of the North Asian Craton basement.

1 - Archean and Paleoproterozoic cratonic terranes (BR - Berekta terrane); 2 - Paleoproterozoic collision belts (KH - Khapchan terrain); 3 - Mesoproterozoic collision belt; 4 - Mesoproterozoic rift and dike belts (nrb - Nyurba rift), 5 - Neoproterozoic rifts and dike belt (bu -Bilir-Udzha, iv - Irkinei-Vanavar, kh Khastakh, kf - Koui-Fomochev, tn - TurukhanKhantai, um -Ust'-Maya, ur - Ura rifts); 6 kimberlite fields: a -Precambrian, b - Paleozoic, c Mesozoic; 7 - highly diamondiferous kimberlites; 8 distribution areas of diamond placers.

This regularity can be explained, to some extent, by the results of isotope dating of xenoliths of the mantle and alkali-ultrabasic rocks from the Yakutian diamondiferous province. According to these data tectonic - thermal events occurred within the upper mantle during the time intervals $1200-1000$ and 800 -
$600 \mathrm{Ma}$, that might result in the formation of kimberlites or convergent rocks (Zaitsev et al., 1985). These supposed epochs were, probably, rather intensive in the northern part of the province, since they could provide a large-scale diamond tenor of the region. The existence of weakly diamondiferous or barren kimberlites in the region in the following epochs may be explained by the evolution of the upper mantle source and its disappearance as a result of endogenic processes that manifested themselves on the periphery of the craton and led to the rifts formation.

\section{Position of diamond placers relative to tectonic structures of the basement}

The heads of the rivers containing placer deposits are either restricted to linear magnetic and gravity anomalies in the basement overlain by Paleozoic and Mesozoic rocks, or they originate nearby the basement uplifts with a Mesoproterozoic sedimentary cover.

Studying the composition and age of xenoliths from kimberlites of the West Ukukit field intruding the BilirUdzha magnetic anomaly, which is interpreted as reflection of a Neoproterozoic rift, revealed the presence of metamorphosed alkaline ultrabasic and basic rocks among the xenoliths. The normative mineral and chemical compositions of the xenoliths indicate the primary rocks were micaceous lamprophyres. Their P-T parameters of metamorphism correspond to jadeite and omphacite stability field. An Sm-Nd model age of the rocks ranges from 700 to 960 $\mathrm{Ma}$, while an $\mathrm{Rb}-\mathrm{Sr}$ isochron age is estimated at $503 \pm 31 \mathrm{Ma}$. The latter value is interpreted as the time of completion of metamorphic processes. The formation of lamprophyres in the Neoproterozoic may be indicative of possible manifestations of both kimberlitic and lamproitic magmatism at this stage of development of the Siberian platform.

The obtained data on the age of xenoliths from the alkali-basic and alkali-ultrabasic rocks do not contradict the assumption made by S.A. Grakhanov et al. (2007), that the Early Mesozoic primary sources were likely very important for the formation of diamond placers in the northeastern Siberian platform. A full range of diamonds of various types first appeared in the Triassic rocks and was later traced in Mesozoic and Cenozoic placers. The age of the primary source was indirectly determined by S.A. Grakhanov et al. (2007) from the age of kimberlite zircons, which occur together with the "Ebelyakh" type diamonds in recent placers (216-233 Ma). Zircons from the Triassic diamondiferous sedimentary rocks yielded similar ages -239-228 Ma. A distribution pattern of diamonds in the Upper Triassic rocks, mineral and petrographic compositions of the latter, and typomorphic features of diamond's indicator minerals suggest that diamondiferous material could have been supplied into the Triassic sedimentary basin from the eastern slope of the Olenek uplift in the south and the 
Ust'-Lena uplift in the north, both of which are made of Precambrian rocks.

$\mathrm{U}-\mathrm{Pb}$ isotopy of zircons from metamorphic rocks of the Ust'-Lena uplift has been studied by A.V. Prokopiev et al. (2007). The age of magmatic protolith for the studied gneisses is estimated at $1909 \pm 5 \mathrm{Ma}$, which is consistent with Paleoproterozoic ages obtained for the basement rocks in the adjacent parts of the Siberian platform. The age value of $156 \pm 17 \mathrm{Ma}$ was determined from the lower intersection of discordia and concordia and reflects a probable age of the basement exhumation in the process of the Late Mesozoic tectogenesis and the related thermal event. It is supposed that the process was accompanied by intense erosion of different-aged primary sources of diamonds.

\section{References}

Afanasiev, V.P., Yefimova, E.S., Zinchuk, N.N. et al., 2000. Atlas of morphology of diamonds from Russian sources. Novosibirsk: SPC UIGGM SB RAS, 298.

Grakhanov, S.A., Shatalov, V.I., Shtyrov, V.A. et al., 2007. Diamond placers of Russia. Novosibirsk. Academic Publishing House "Geo". 457 (in Russian).

Koptil', V.I. and Bilenko, Yu. M., 1980. Typomorphism of diamonds from placer deposits in the northeastern Siberian platform. In: Scientific prognostic methods for search and evaluation of diamond deposit. Novosibirsk, 114-118 (in Russian).

Prokopiev, A.V., Toro, J., Smelov, A.P. et al., 2007. The Ust'-Lena metamorphic complex (northeast Asia). In : First U-Pb SHRIMP geochronological data. In: Otechestvennaya Geologiya, 5, 26-30 (in Russian).

Rosen, O.M., Condie, K.C., Natapov, L.M., and Nozhkin, A.D., 1994. Archean and Early Proterozoic evolution of the Siberian craton: a preliminary assessment, in Condie, K.C., ed., Archean crustal evolution: Amsterdam, Elsevier, 411-459.

Smelov, A.P. and Timofeev, V.F., 2007. The age of the North Asian Cratonic basement: An overview. Gandwana Research 12, 279-288.

Zaitsev, A.I., Nikishov, K.N., Nenashev, N.I. and Kovalskiy, V.V., 1985. Evolution of $\mathrm{Sr}$ - isotope composition in kimberlite rocks of the Yakutian province. In: Petrologic - geochemicar characteristics of deep evolution of the matter of kimberlitic and basitic magmatic systems. Yakutsk, 13-37 (in Russian). 